\title{
ISOLATION OF THE BACTERIUM, VIBRIO HARVEYI FROM CULTURED SHRIMP, PENAEUS MONODON AND PRODUCTION OF VACCINES AGAINST THE BACTERIUM
}

\author{
M. HETTIARACHCHI ${ }^{*}$, S.G. PATHIRAGE ${ }^{2}$ and D.C. HETTIARACHCHI ${ }^{3}$ \\ 1 Department of Zoology, University of Kelaniya, Kelaniya. \\ 2 Department of Botany, University' of Kelaniya, Kelaniya. \\ ${ }^{3}$ Microbtek Laboratories (Pvt.) Ltd, Christian Perera Place, Dalugama, Kelaniya.
}

(Accepted: 14 November 2005)

\begin{abstract}
Disease outbreaks detected by the presence of a large number of luminescent post larvae in larval rearing tanks followed by heavy mortalities, have been recorded in most of the shrimp hatcheries in Sri Lanka. Broad spectrum antibiotics, probiotics, and occasionally, imported vaccines have been used indiscriminately to control the disease. In this study, a pathogenic bacterium causing luminescence and heavy mortalities in post larvae was isolated from seven shrimp hatcheries situated in the North Western Province. The bacterium was characterized and identified as a strain of Vibrio harveyi using standard microbiological tests and biochemical reactions of bacteria. Two vaccines (Formalin killed and heat killed bacteria) were prepared from the isolated strain of $V$. harveyi and two groups of eighteen day old healthy post larvae $\left(\mathrm{Pl}_{18}\right)$ were vaccinated separately by immersion technique. Efficacy of both vaccines were then evaluated by challenging vaccinated post larvae after different week intervals from vaccination with the same bacteria. Mean percentage survival of post larvae vaccinated with formalin killed vaccine and heat killed vaccine after 3 weeks from vaccination were $81.62 \%$ and $80.22 \%$ respectively which were significantly higher $(\mathrm{p}<0.05)$ than that of the post larvae which were not vaccinated and used as the control $(35.21 \%$ and $37.89 \%$ ) confirming that the vaccines were effective.
\end{abstract}

Key words: Cultured shrimp, Penaeus monodon, Sri Lanka, vaccines, Vibrio harveyi.

\section{INTRODUCTION}

The number of diseases affecting cultured penaeid shrimp has increased steadily with the expansion and intensification of large scale commercial culture systems. ${ }^{1,2}$ Among the recognized causative agents of infectious diseases of shrimp are viruses, bacteria, rickettsia, fungi, and protozoa. There are heavy production losses due to viral and bacterial diseases. ${ }^{2}$

Bacterial diseases have continued to parallel the growth of the industry in importance. ${ }^{2}$ Among the bacterial infections, vibriosis caused by different species of Vibrio is recognized to be the most important in initiating mass mortalities in cultured shrimp in East and South East Asia. ${ }^{3-6}$ It has been pointed out that there has been wide spread use of antibiotics as a remedial measure against bacterial diseases in shrimp hatcheries. However, it is becoming less and less effective as new strains of bacterial pathogens evolve, which are resistant to commonly used antibiotics. Antibiotics could leave residues in shrimp which could have implications in human health. Therefore, other forms of prevention and control methods are suggested for bacterial diseases and use of vaccines is among them. ${ }^{8}$ Antibiotics such as oxytetraxycline, oxolenic acid, and even chloramphenicol are widely used in shrimp hatcheries which could leave residues in shrimp and could be toxic to humans and also develop antibiotic resistance in bacteria. ${ }^{9}$

Shrimp industry in Sri Lanka has experienced two major viral diseases; outbreaks of Monodon Baculo Virus (MBV) disease in 1989/ 90 killing post larvae in hatcheries and White Spot Syndrome Virus (WSSV) disease in 1996 causing heavy mortality in shrimp in grow-out ponds. ${ }^{10}$ Recurrence of WSSV disease has been the major cause of low cultured shrimp production in Sri Lanka since 1999. ${ }^{11}$ Though there is no published literature, disease outbreaks detected by the presence of a large number of luminescent post larvae in larval rearing tanks followed by heavy mortalities have been recorded in most of the shrimp hatcheries. The luminescence disease condition is not uncommon even in juvenile shrimp in grow-out ponds.

Vaccines composed of inactivated Vibrio species ${ }^{12,13}$ are reported to protect different species of shrimp from vibriosis for varying

" Corresponding author 
periods of time and to improve survival, growth and quality of vaccinated shrimp. ${ }^{13-16}$ Possible effects of these vaccines on the defence system of shrimp have been discussed. ${ }^{17-20}$ Most of the local hatcheries use broad spectrum antibiotics and some probiotics to control mortality in larval stages while probiotics are widely used in growout ponds. Some local shrimp hatchery owners have used imported vaccines to control mortality caused by luminescence disease without positive results. [Personal communication, Mr. Hasitha Thammannagama, Aqua Breed (Pvt.) Ltd, Ambakandawila]. As the strains of bacteria present in local shrimp hatchery systems could be different from the strains present in other countries, it is important to produce vaccines locally rather than importing them. The present study was planned to isolate and identify a common luminous bacterium which caused heavy mortalities of post larvae in some commercial hatcheries, produce vaccines and evaluate the efficacy of the vaccines produced in protecting post larvae when challenged with the same species of bacteria in the live form.

\section{METHODS AND MATERIALS}

Isolation and identification of pathogenic luminous bacteria: Seven shrimp hatcheries in the North Western Province, where mortality of post larvae was reported due to luminescence disease condition from May 2002 to January 2003 were selected for the study. The methodology used by Hung-Hung et $a l^{21}$ was slightly modified in isolating the bacterium. Moribund post larvae from each hatchery were randomly selected, and luminous bacterium was isolated on ThiosulphateCitrate -Bile-Salt Sucrose (TCBS) agar. Stock cultures were prepared and stored separately. Each isolate was identified separately using standard tests ${ }^{22,23}$ and the results of biochemical reactions including the tests incorporated to API $20 \mathrm{E}$ miniaturized identification test strip (bio Meriux, France). Morphological and physiological characteristics and biochemical reactions of the bacterial isolates were compared with those of luminous Vibrio species isolated from Vietnam and $V$. harveyi type strain from Aquatic Animal Health Resource Institute (AAHRI), Thailand. ${ }^{23}$
Preparation of vaccines: Preliminary investigations were carried out to determine the minimum concentration of formalin and minimum temperature required to kill the isolated bacterium completely. Using stock cultures, confluent growth of the isolated bacterium was obtained and two bacterial suspensions were prepared in sterilized distilled water with $2 \%$ $\mathrm{NaCl}$. Formalin $(0.2 \%)$ was added to one suspension and the other suspension was heated in a water bath (up to $75{ }^{\circ} \mathrm{C}$ ) in order to kill the bacteria completely. After confirming that there were no viable bacteria, optical density of the suspension was measured at $350 \mathrm{~nm}$ in a spectrophotometer (LED sp -380 Digital, Barnstead and Thermoline, USA) and cell density of both suspensions were made equal by aseptical dilution. The suspensions with bacteria killed by formalin and heat were taken as vaccine 1 and 2 respectively (vaccines were freshly prepared when trials of vaccination were conducted).

Vaccination of post larvae: A static experimental system consisting of $2 \mathrm{~L}$ conical flasks was employed for vaccination. Each conical flask was filled with UV sterilized sea water with salinity of $32 \mathrm{gL}^{-1}$ and aerated individually. The water temperature was recorded and hundred apparently healthy, acclimatized, $18 \mathrm{~d}$ old post larvae $\left(\mathrm{Pl}{ }_{18}\right)$ were placed in each conical flask. Vaccination was carried out by immersing the first two groups of post larvae separately in vaccine 1 and vaccine 2 respectively for $5 \mathrm{~min}$. The third group (control) did not receive any vaccination. Vaccinated and non vaccinated post larvae were fed with a commercially available post larval feed (at the feeding regime recommended by the feed manufacturer) and maintained within optimum water quality parameters for periods of $1 \mathrm{wk}, 2$ wks and 3 wks (three replicates were arranged for each vaccine and for each time period with three controls for each treatment) and subjected to challenge experiments at the end of each period of time separately.

Challenge test: Suspensions of live isolated bacteria (cell density of $5 \times 10^{4} \mathrm{cfu} / \mathrm{mL}$ ) were prepared in $0.8 \%$ sodium chloride and the post larvae in each test and the control group were 
Table 1: Characteristics of isolated bacteria in the present study compared to Vibrio harveyi isolated in Vietnam and Thailand.

Characterization test

$\begin{array}{cc}\text { Bacteria isolated } & V . \text { harveyi } \\ \text { during the present } & \text { isolated in Vietnam }\end{array}$
study
$V$. harveyi type strain (43516) from AAHRI, Thailand
Luminescence of bacteria

Gram staining

Haemolysis

Swarming

Motility

Catalase

Oxidase

Pigment production

Growth on TCBS agar

Growth in $0 \% \mathrm{NaCl}$

$3 \% \mathrm{NaCl}$

$6 \% \mathrm{NaCl}$

$10 \% \mathrm{NaCl}$

Growth at $4 \mathrm{C}^{0}-5 \mathrm{C}^{0}$

$26 \mathrm{C}^{0-} 27 \mathrm{C}^{0}$

ONPG

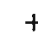

$\mathrm{ADH}$

LDC

ODC

CIT

$\mathrm{H}_{2} \mathrm{~S}$

Urease

TDA

IND

VP

GEL

\section{Utilization of carbon sugars}

Glucose

Arabinose

Mannitol

Sucrose

Inositol

Sorbitol

Rhamnose

Melbiose

Amygdelin

Nitrate reduction test

OF-F test

OF-O test

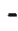

$+$

$+$
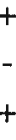

$+$
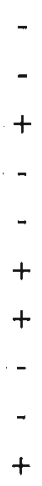

$-$

$+$

$+$
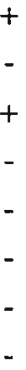

+
-
+
-
+
+
+
-
+
-
+
+
-
+

Not done

Not done

Not done

Not done

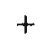

-

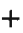

$+$

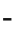

$+$

$+$

Not done

Not done

Not done

Not done

Not done

$+$

$+$

$+$
Not done

Not done

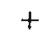

-

$+$

$+$

$+$

$+$

$+$

Not done

Not done

Not done

Not done

Not done

$+$

$+$

$+$

${ }^{*}$ Characteristics of $V$. harveyi in Vietnam and AAHRI (Thailand) were obtained from published literature. ${ }^{23}$ 
Table 2: Percentage survival of vaccinated Penaeus monodon post larvae (with formalin killed bacteria, vaccine 1 and heat killed bacteria, vaccine 2) after 1 week, 2 weeks and 3 weeks from vaccination.

Mean percentage survival \pm SE

Treatment

Time from vaccination

\begin{tabular}{lccc} 
& One week & Two weeks & Three weeks \\
\cline { 2 - 4 } $\begin{array}{l}\text { Formalin killed bacteria } \\
\text { (Vaccine 1) }\end{array}$ & $86.51^{\mathrm{a}} \pm 2.441$ & $83.23^{\mathrm{a}} \pm 1.921$ & $81.62^{\mathrm{a}} \pm 3.103$ \\
Control & $66.04^{\mathrm{b}} \pm 4.625$ & $54.47^{\mathrm{b}} \pm 2.033$ & $35.21^{\mathrm{b}} \pm 4.228$ \\
$\begin{array}{l}\text { Heat killed bacteria } \\
\text { (Vaccine 2) }\end{array}$ & $85.37^{\mathrm{a}} \pm 3.718$ & $82.29^{\mathrm{a}} \pm 1.210$ & $80.22^{\mathrm{a}} \pm 2.996$ \\
Control & $62.75^{\mathrm{b}} \pm 2.405$ & $51.38^{\mathrm{b}} \pm 3.776$ & $37.89^{\mathrm{b}} \pm 5.001$ \\
\hline
\end{tabular}

Values in the same column with different superscript are significantly different from each other ( $\mathrm{p}<0.05$; One way ANOVA and Tukey's pairwise test)

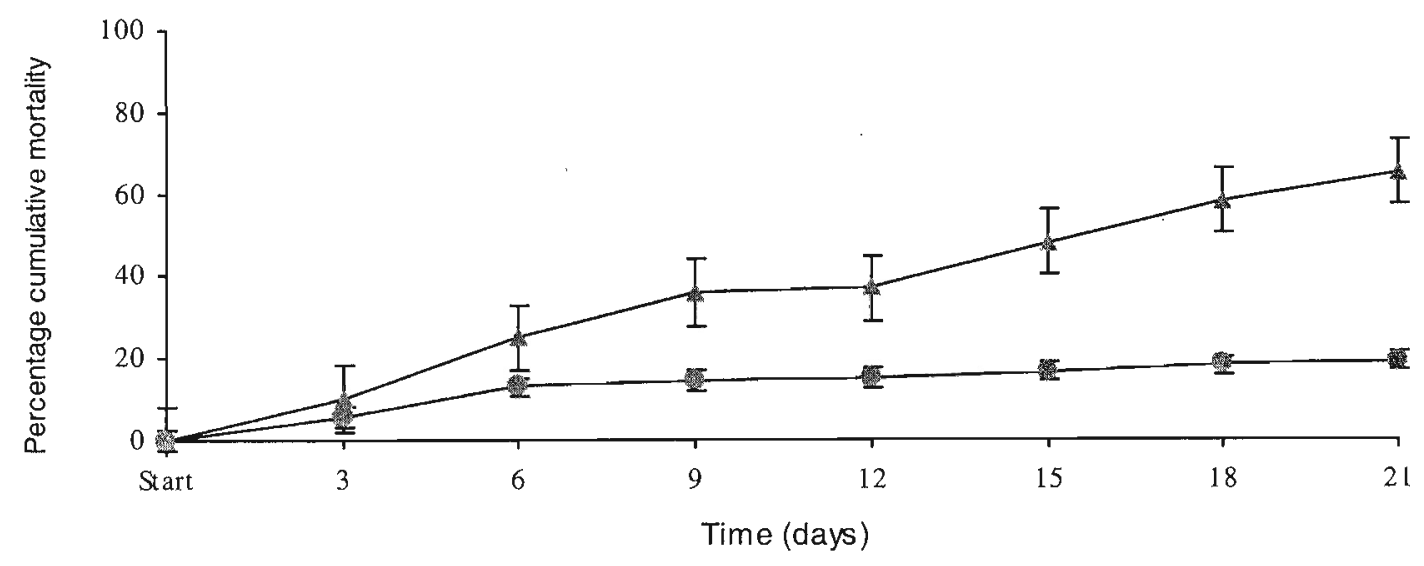

$\rightarrow$ Treated Control

Figure 1: Mean percentage cumulative mortality of Penaeus monodon post larvae ( \pm S.E.) treated with formalin killed isolated bacteria (vaccine1) when challenged with the same bacteria in live form.

challenged separately by immersing in the suspension for $5 \mathrm{~min}$. After the challenge experiment, mortality of juveniles in each group was recorded daily for $3 \mathrm{wks}$ and randomly selected moribund shrimp juveniles were used to inoculate TCBS agar plates separately to investigate whether they were infected with the challenged bacteria.

\section{RESULTS}

Results of the standard microbiological tests and biochemical reactions of isolated bacteria, including the tests incorporated to API $20 \mathrm{E}$ rapid diagnostic system performed to identify the bacteria are given in Table 1 together with the characteristics of $V$. harveyi isolated in Vietnam and Thailand. 
It was found that the bacteria isolated from all 7 hatcheries had the same characteristics and were almost identical to $V$. harveyi isolated in Vietnam and Thailand (Table 1); therefore the bacteria isolated could be a strain of $V$. harveyi.

Mean percentage survival recorded for vaccinated post larvae after 1 week, 2 weeks and 3 weeks from challenging with live bacteria was significantly higher than that of non vaccinated post larvae ( $p<0.05$; Table 2$)$. This indicates that vaccinated eighteen day old post larvae (with each vaccine) have achieved protection against the tested strain of $V$. harveyi for a period of 3 weeks while non vaccinated group was susceptible to the luminous vibriosis caused by the same strain of $V$. harveyi. Figures 1 and 2 show the mean cumulative mortality ( \pm S.E.) of vaccinated and non vaccinated post larvae over 3 weeks.

Moribund juveniles from both control and experimental groups that were inoculated on TCBS agar resulted in bluish green colonies with luminescence in the dark confirming that they were infected with $V$. harveyi used for the challenged experiment.

\section{DISCUSSION}

Gram negative bacteria of the genus Vibrio have frequently been implicated worldwide in cultured penaeid shrimp disease outbreaks in all phases of production. ${ }^{5,6}$ The major biochemical characteristics of luminous bacteria isolated from seven hatcheries during the present study were similar to those of $V$. harveyi strains isolated from a disease outbreak in a shrimp hatchery in Vietnam and those of the typed strain (43516) from the AAHRI, Thailand. Therefore, it is concluded that the isolated luminous bacterium in this study is a strain of $V$. harveyi.

Both vaccines prepared with the isolated strain of $V$. harveyi (formalin killed bacteria and heat killed bacteria) protected post larvae of $P$. monodon from the bacterium, $V$. harveyi in live form (when exposed after 1 week, 2 weeks and 3 weeks from vaccination) resulting higher survival (above 80\%) compared to post larvae that were not vaccinated (less than 38\%). Most of the vaccines available in the market are simple bacterins which have been chemically or heat attenuated to alter the virulancy. ${ }^{12-15}$ The vaccines produced in this study is similar in this respect.

A vaccine produced with formalin inactivated strains of $V$. harveyi, $V$. alginolyticus, $V$. parahaemolyticus and $V$. vulnificus has improved disease resistance, given protection against vibriosis and luminous vibriosis (resulting higher survival). ${ }^{13}$ The growth rate and quality of vaccinated shrimp were also significantly improved in the hatchery and in the grow out stage. $^{13,16}$

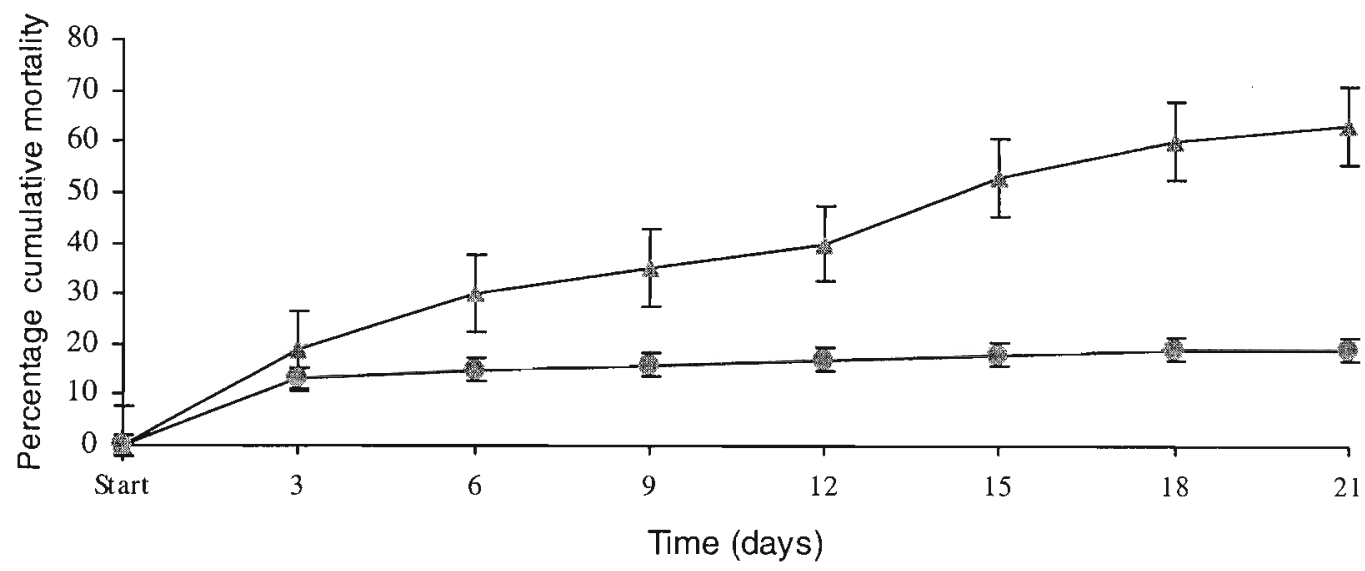

一 Treated $\rightarrow$ Control

Figure 2: Mean percentage cumulative mortality of Penaeus monodon post larvae ( \pm S.E.) treated with heat killed isolated bacteria (vaccine 2 ) when challenged with the same bacteria in live form. 
Increased survival rates observed in shrimp post larvae during the present study after vaccination with both vaccine preparations could have been due to a combination of immunological reactions by the post larvae in response to the attenuated bacteria. Various aspects of Vibrio vaccines have been studied; heat killed Vibrio cells enhanced the phenoloxidase activity (in the proPoactivating system ${ }^{17}$ )as immunostimulants. ${ }^{15}$ Higher survival rate and higher phagocytic index has been observed in vibrio vaccinated shrimp when compared to shrimp that were not vaccinated. ${ }^{3}$ Oral, bath and injection administration of immunostimulants, such as Vibrio bacterin, $\beta$-glucan and peptidoglycan could increase the resistance of shrimp against microbial infections. ${ }^{15} \beta$-glucan and peptidoglycan are bacterial cell wall components. ${ }^{18}$ These components in the cell walls of dead Vibrio cells in formalin killed and heat killed vaccines in this study could have acted as immunostimulants resulting in higher survival during the challenge experiment. It has been pointed out that the nonspecific immune system of shrimp functions as an immunological memory to prevent new infections caused by pathogens. ${ }^{19}$ Following immersion or oral ingestion of Vibrio bacterin, the shrimp showed significant resistance against the challenge with $V$. harveyi, a virulent bacterium. ${ }^{3}$ The study showed that, under laboratory conditions post larvae of Penaeus monodon when exposed to formalin and heat killed $V$. harveyi strain could achieve an effective protection against luminous vibriosis caused by the same bacteria up to 3 weeks indicating potential use of these vaccines.

Some researchers have pointed out that as shrimps lack a well developed specific defence system, any enhancement of its defences against pathogens can only be for a short time. ${ }^{20}$ Others have showed that the immunity achieved by post larvae of Penaeus sytlyrostris after vaccination with a Vibrio species lasted for 4 months which is sufficient to complete one culture cycle. ${ }^{15}$

Results of this study do not support the view that vaccination of shrimp is meaningless, since they do not have immunological memory response. ${ }^{8}$ It has also been stated that increasing resistance of shrimp to a single specific pathogen cannot protect them from other pathogens during the culture period. ${ }^{15}$ Therefore, in order to protect shrimp from vibriosis, it is important to isolate and identify other pathogenic Vibrio species common in shrimp hatcheries and grow out systems in Sri Lanka and develop vaccines incorporating all these Vibrio species.

\section{References}

1. Flegel T.W. (2002). Emerging shrimp diseases and innovations to prevent their spread. In: Diseases in Asian Aquaculture Vol. IV. (Eds.S C.R. Lavilla-Pitogo \& E.R.Cruz-Lacierda.). pp. 137-149.Fish Health Section, Asian Fisheries Society, Manila.

2. Lightner D.V., Bell T.A., Redman R.M., Mohney L.L. , Natividad J.M. , Rukyani A. \& Poernomo A.(1992). A review of some major diseases of economic significance in Penaeid prawns / shrimps of the Americas and Indo-pacific. . In: Diseases in Asian Aquaculture. Vol. II. (Eds. M. Shariff, J.R. Arthur \& R. Subasinghe). pp. 5780.Fish Health Section, Asian Fisheries Society, Manila.

3. Kwei L.C. \& Nash G.L. (1996). Vaccine for shrimp culture, Asian Shrimp News (collected volume, 1989 - 1995.) p.129, Asian Shrimp Culture Council, Bangkok.

4. Ruangpan L. \& Kitao T.(1991).Vibrio bacteria isolated from black tiger shrimp, Penaeus monodon Fabricius. Journal of Fish Diseases 14: 383-388.

5. Brock J.A. (1992).Shrimp disease diagnosis and control short course. Training course notes. p. 165 Shrimp Culture Research Centre, C.P. Mahachai, Thailand.

6. Kwei L.C. \& Nash G.L. (1996). Luminous bacterial infection in pond reared Penaeus monodon. Asian Shrimp News (collected volume, 1989 - 1995.) pp. 182-187. Asian Shrimp Culture Council, Bangkok.

7. Jiravanichpaisal P., Puanglarp N., Traisresin C., Pongtunya P., Chanratchakool P. \& Menasveta P. (2002). Growth promotion and enhancement of vibriosis resistance in penaeid shrimp after 
oral administration of lactic acid bacteria and marine bacteria. In: Diseases in Asian Aquaculture Vol. IV. (Eds. C.R. Lavilla-Pitogo \& E.R.Cruz-Lacierda). pp. 93-103. Fish Health Section, Asian Fisheries Society, Manila.

8. Anitha G. \& Goswami M. (2000). Disease diagnostic and health management tools in Aquaculture. INFOFISH International 5: 18-23.

9. Primara J.H. (1998). Tropical shrimp farming, and its sustainability. In: Tropical Mariculture. (Ed. Sena de Silva). pp. 257-259, Academic press, London.

10. Jayasinghe J.M.P.K. (1997).White spot virus: How Sri Lanka copes. Aquaculture Asia 9:46-47.

11. Annual report of Central Bank of Sri Lanka. (1999).Central Bank of Sri Lanka, Colombo.

12. Plumb J.A. (1995).Chemotherapy vs. vaccination: A reality for Asian Aquaculture. In: Diseases in Asian Aquaculture II. (Eds. M. Shariff, J.R. Arthur \& R. Subasinghe). pp 4553. Fish Health Section, Asian Fisheries Society, Manila.

13. http//:www. Aqua feed /correspondents.html

14. Itami T. \& Nakayama Y.(1989). Efficacy of vaccination against vibriosis in cultured Kuruma prawn, Penaeus japonicus. Journal of Aquatic Animal Health I: 238-242.

15. Song Y. \& Huang C. (2000). Application of immunostimulants to prevent shrimp diseases. In: Recent advances in marine biotechnology, Vol.5. (Eds. R.M. Redman \& L.L. Mohney) pp. 173-187. Science Publishers Inc. New Hampshire, USA.
16. Sung H.H. \& Song Y.L.(1996).Tissue location of Vibrio antigen deliverd by immersion to tiger shrimp (Penaeus monodon). Aquaculture 145:41-54.

17. Bachere E. (2000). Shrimp immunity and disease control. Aquaculture 191: 3-11.

18. Nester E.W., Roberts C.E., Pearsall N.N., Anderson D.G. \& Nester M.T.(1995). Microbiology - A human perspective. pp. 45-84. The McGraw-Hill company, USA.

19. Ceulamans S., Coutteau P., Trot L. \& Rottlant $J .(2002)$. Supplemented feeds stimulate immune systems of Gilthead sea bream. Global Aquaculture Advocate 10 : 24 - 25.

20. Wang Y.G., Shariff M., Sudha P.M., Sirinivasa Rao P.S., Hassan M.D. \& Tan. L.T.(1998). Managing white spot disease in shrimp. INFOFISH International 3:11.

21. Hung-Hung S., Shi-Fang H., Chih-Kun C., YunYuanT. \& Wei-liang C. (2001). Relationships between disease outbreak in cultured tiger shrimp (Penaeus monodon) and the composition of Vibrio communities in pond water and shrimp hepatopancreas during cultivation. Aquaculture 192: 101-110.

22. Frerichs G.M. \& Millar S.D.(1993). Manual for the isolation and identification of fish bacterial pathogens. p.60.Pisces press,Stirling, UK .

23. Onah D.T.H., Pedersen K. \& Larsen J.L. (2002). Identification and characterization of Vibrio bacteria isolated from fish and shellfish in Vietnam. In: Diseases in Asian Aquaculture Vol. IV. (Eds.C.R. Lavilla-Pitogo \& E.R.CruzLacierda). pp. 73-86. Fish Health Section, Asian Fisheries Society, Manila. 